\title{
Development Needs of Dairy Farms in Kosovo
}

\author{
Tiina Kokko ${ }^{1,2}$; Kati Partanen ${ }^{1}$; Hilkka Kämäräinen ${ }^{1}$; Ardita Jahja-Hoxha ${ }^{3}$; Jussi Juhola ${ }^{4}$ \\ 1. Savonia University of Applied Sciences, P.O.box 72, 74101 Iisalmi, Finland, \\ forename.surname@savonia.fi \\ 2. MTT, Domestic animal research, Halolantie 31A, 71750 Maaninka, Finland, \\ tiina.kokko@mtt.fi \\ 3. University of Prishtina, Agriculture and Veterinary Faculty, Boulevard "Bill Clinton", no nr. \\ 10000 Prishtina, Kosovo, ardita.hoxha@uni-pr.edu \\ 4. Association of ProAgriaCentres, P.O Box 251,01301 Vantaa, jussi.juhola@proagria.fi
}

\begin{abstract}
The Republic of Kosovo in Western Balkans has raised agriculture as one of its development priorities. Farms are still mainly small and agricultural production poorly developed. Most of the agricultural products in retail stores are imported. The goal of this study was to define development needs of Kosovan dairy farms by observing farm operations.

Observations were made in March 2012 by following the work of a farmer in 13 different sized dairy farms. Farmers were also interviewed. The results show that most development needs in milk production are milking hygiene, cleanliness of the milking facility, feeding and heat detecting. For example hoof care and animal welfare were usually at agood level in the observed farms.

The size of the observed farms varied between 6 to 115 dairy cows. Milking was done in the smallest farm by hands, ninehad bucket milking system and threepipeline milking system. The observed farms can be classified as semi-commercial and commercial farms which deliver most of their milk to the processor. The main problems in the observed farms were poor milking hygiene and poor cleansing of the milking equipment. This can be also seen from the milk quality of the observed farms: according to somatic cells five farms were in Extra class and 5 in I-class (no information available in 3 farms). In number of bacteria 3 farms were in Extra class, 6 in I-class, 2 in II-class and 1 in III-class (no information available in 1 farm). Especially bucket milking system and in some cases the milking tank seemed to be difficult to clean. In some farms the condition of the milking machine seemed to be poor.

The time between calvings was long, on average 432 days. There might be lack of heat detection. Also fertility may be low due to wrong feeding of the cows. The time between calvings was lowest on farms using only natural insemination (396 days) and longest in farms using both natural and artificial insemination (470 days). In farms using only artificial insemination the time between calvings was 444 days. Lactations per cow was on average 3,86. None of the interviewed farmers had agricultural education.

An average farm size in Kosovo is about 2,2 hectares of field and about two milking cows. The average milk yield is estimated to be around $2200 \mathrm{~kg} /$ year. The biggest problems in milk processors are poor quality of milk and variations in milk received during the year: in summer processors have troubles in using all the milk and in winter the milk production of farms is too low. Only about $10 \%$ of the milk produced is delivered to the processors.

The future of agriculture looks bright in Kosovo as all interviewed farmers were willing to develop their farm and saw the future positive. Agricultural advisory (extension) services and the availability of training for farmers play a vital role in improving the basic environment for farming as well as farm profitability.
\end{abstract}

Keywords: dairy farms, Kosovo, observing 


\section{Introduction}

The dairy sector is one of the fastdeveloping sectors of agriculture in Kosovo. Unfortunately farming and agriculture are mostly inefficient. Machinery is mostly primitive or it is not used. Usually farming is subsistence farming but there is plenty of potential for developing agriculture. The soil is mostly suitable for agriculture and the climate is warm enough. Drought can cause problems in some parts of Kosovo. The average size of a dairy farm in Kosovo is very small, 2,2 hectares of field and 2 dairy cows (Vehapi 2009, 22). Most small farms produce only for their own consumption. Only about $10 \%$ of the milk produced is delivered for dairies for processing (Nushi \& Selimi 2009, 4). There are 16 registered and certified dairy processors in Kosovo (Jahja-Hoxha 2012b).

The client organization of the studywas TAGAK (Training of Agricultural Advisors in Kosovo) -project financed by the Ministry for Foreign Affairs in Finland. The project was realized by Savonia University of Applied Sciences in Finland, Association of ProAgria Centres in Finland and University of Prishtina in Kosovo. The goal of the project was to train 20 agricultural advisors from municipalities and secondly to develop the Agriculture and Veterinary Faculty of University of Prishtina as well as the Ministry of Agriculture, Forestry and Rural Development (MAFRD) in Kosovo. The project was realized between October 2011 and November 2013.

The study gives information about the current situation of dairy production in Kosovo: breeds used, feeding, milk yield and machinery. The work is about commercial and semi-commercial farms that are willing to develop. Bigger farms also have greater ability to change.The methods used and results received from the visits to farms are reported: e.g. their working and feeding methods. The study was limited to dairy farms because dairy production is currently developing fast and extra knowledge is crucial. A visit to Kosovo was made during 11th - 18th March 2012. Different methods were evaluated and compared to regular methods in Finnish. The information received was given to University of Prishtina to be used when training new advisors. The evaluation was based on the Finnish dairy cow herding methods and knowledge.

\section{Material and methods}

The research included a questionnaire, an interview, observation and evaluation. These techniques were combined when finding out the development needs of Kosovan dairy farms. It was crucial to observe the farmers in action on their own farms which is why the visits were the most important part of the study. Besides the participatory observation, interviews of the farmers were needed. The studies questionnaire was filled in during the interview and some questions got clarification.

Observation is the most direct way of collecting data. A risk of choosing observation is that people observed may play some kind of a role when observed (Gillham 2003, 46).For this reason both observation and interviews were used and also the animals and their environment were observed carefully.

The questions were selected to find out the real improvement needs of Kosovo dairy sector. Especially the critical points affecting the quality of milk were wanted to be found out. Also knowing specific feeding methods was important.Translation from Albanian to English was needed as most of the farmers interviewed couldn't speak English.

The farms were chosen by University of Prishtina's Faculty of Agriculture and Veterinary to represent a variation of commercial and semi-commercial dairy farms. Some farms were chosen randomly during the round in the villages, as more variation to the farms was needed.

\section{Results and discussion}

The farms observed were bigger than an average farmthe amount of cows varying between $6-115$ cows, as in Kosovo the average farm size is two cows. The most popular breed used was Black Holstein followed by Simmental, Red Holstein and cross breeds (Figure 1). 


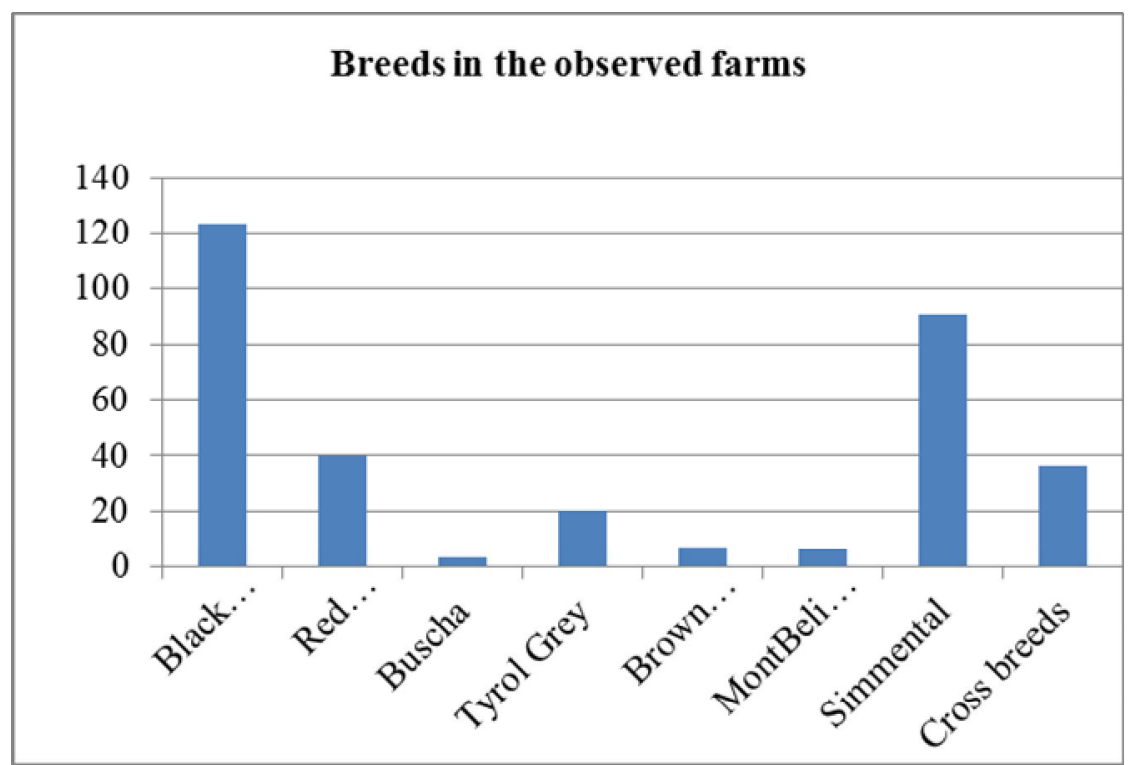

Figure 1. The breeds in the observed farms (number of cows in total)

The welfare of the animals seemed to be in general fine. Animals are relatively clean and they are not too fat or thin. Manure behind the cows looked nice and no diarrhea was seen in the cowsheds. According tothisfeeding is at a good level even though it seems not to be well planned, e.g. almost every cow gets the same amount of concentrate regardless of how much she milks or if sheisdry. Maybe giving plenty of hay compensates fiber given. Silage and concentrate given should be analyzed. It is important especially if having any problems e.g. with fertility. It is easier to find an answer if it is known how much e.g. minerals, trace elements, possible mold and $\mathrm{pH}$ there are in the feeds. The most important thing is to know what feed is possibly missing and if there is something too much. It is possible to fix feeding with minerals if the quality of feed given is known.

Feeding is usually done manually and it is hay-based. Concentrate and maize silage is given in various amounts. Grazing and feeding should be better planned in general. Cows may graze in ditches and probably feeding values are not the best there. Pastures that are well taken care of give more milk from the cows and cows stay healthier.

Calves are given milk forthree months but also roughage, concentrate and water should be offered for calves right from the beginning. Some of the observed farmers did it already but some did not. Antibiotic milk should not be given to calves because it causes resistance to antibiotics.

The health situation seems to be rather good. One observed farm had problems with calve diarrhea and ring worm. One farm had a problematic cow with multiple mastitis but mastitis in general was not considered a problem. Antibiotic residues should be tested. A very positive thing was to notice that farmers take care of their cows' hooves.

Many farmers seem to do things right. However, many of the observed farms had high Total Count of bacteria in the milk and the reason was not clear (Table 1).

Table 1.Milk quality in the observed farms.

\begin{tabular}{lccccc} 
& Extra & Class I & Class II & Class III & No information \\
\hline Somatic cells & 5 & 5 & & & 3 \\
\hline Number of bacteria & 3 & 6 & 2 & 1 & 1 \\
\hline
\end{tabular}

The problem could be water or the working methods were not actually always as careful as told. Water was told to have been analyzed and the quality of it was said to be good but nobody knew the exact results. The farmers described their washing routines well and everything seemed to be done in a right way. One problem might also be poor washing of the bucket milking system, which could be cleaned with the help of a vacuum. Hoses would be easy to clean up and washing would be fast. All that is needed is a clean bucket, warm water for first rinsing, hot water, washing liquid, vacuum and hot rinsing water. Washing with a brush is slower and hoses are difficult to keep clean. Every observed 
cow house was neat inside though some farms were unclean outside. The results of the analyzed water should be given to farmers. Also the water from wells should be analyzed. Good advice is to change all hoses at the same time and start washing the bucket milking system with the help of a vacuum after that.

Every cow should have her own towel or as manyas needed in order to achieve a clean udder and teats. Towels should not be wet but moist. Using water is not recommended when cleaning up the udder. Dirty water drops may drain from the udder to the teats and allow bacteria into the milk. First drops should be taken and if needed also CMT. The milking machine should not be putonto the teats before the udder is ready and the milk comes out properly. If using dipping or spray after milking, there should be left a drop of it at the top of the teat.

The temperature of the milk should be measured after milking and it was not clear if the farmers do that. It should be cooled down to $<4^{\circ} \mathrm{C}$, the preservative temperature, as soon as possible but it should not be frozen. There should be no problems with the temperature of the milk if the farm has a proper milk tank but some farms cool down the milk in a freezer since they donot have a milk tank. Temperatures would be good to write down on paper before milking and right after milking. Also the milk in the tank should be mixed regularly. Every farmer should have a proper cooling system.

In the observed farms both artificial and natural insemination were used. Fertility and the time from one calving to another seemed to be a problemin some farms. The time between calvings was longest when using both artificial and natural insemination, 470 days and shortest in farms using only natural insemination, 396 days. It was not clear why the difference occurred. The reason could be thata bull is used only if cows do not become pregnant after trying artificial insemination several times.Other reasons for the long time between calvings could be problems in feeding, wrong timing in artificial insemination and problems in heat detection. Only veterinary is allowed to do artificial insemination in Kosovo and as there is not enough veterinarians, the artificial insemination may be done at a wrong time.

Statistics of the fertility of dairy cows in Kosovo were not available. It would have been interesting to know e.g. how many times they inseminate cows per calving in general, how many days it takes to start inseminating after calving, how old heifers are when they calve for the first time and how many days is required from one calving to another in general. According to the results of the research, the time from one calving to another is too long. It should be improved e.g. by better heat detection, timing and feeding.

The majority of the observed farms had a bucket milking system (Figure 2).

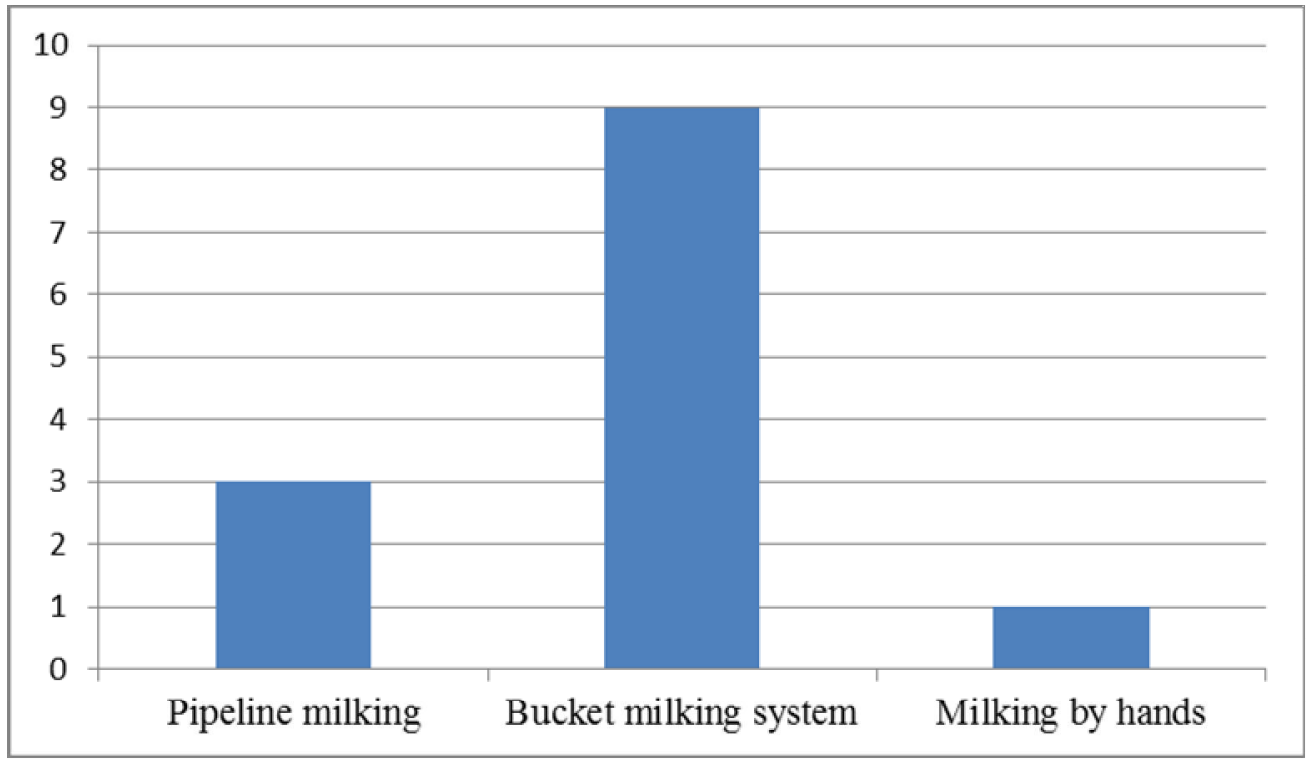

Figure 2. Milking techniques in observed farms. (Number of farms)

The farms having a pipeline milking system seemed to have a better quality of milk both in bacteria and in somatic cells than farms with a bucket milking system or who were milking by hands. The data of the quality of milk in general in the small farms was not available. If the farm only produces milk 
for its own consumption the data is not collected. Maintenance of the milking machine is usually done by the farmer. It would be good if a professional would check the milking system at least once per year. Every farmer should also use a single use filtering system and not a fabric washed after use.

\section{Conclusions}

Many recommendations for the farmers to improve the production are easy to implement. Some of them need advisory services, for example right milking and equipment cleaning techniques. Some of them require more attitude change, as using protective clothing when moving from one farm to another is a simple to prevent diseases, like diarrhea and ring worm to spread. Testing antibiotic residues can be easily done if equipment is bought for that. The temperature of milk should always be measured when cooling it. The temperatures would be good to write down. Providing good housing conditionsfor cows makes their resistance against diseases stronger. A good temperature, e.g. reducing heat stress, can be achieved with air conditioning and with cool water sprays. Feeding is an important part of dairy production which has effects onheat, milk production, consistence of milk and a cow's resistance against diseases. A regular maintenance for the milking machine should be done yearly. Also checking daily the vacuum, oil level and functioning of the milking machine in general is important.

Bookkeeping on everything is very important. For instance, how many times a cow is inseminated per pregnancy, what medicines (and how often) are given for cows, milk yields produced (measuring them monthly), the time between calving, how old the heifers are when they calve for the first time would be good to know. Practices in artificial insemination should be examined to ensure right timing for the insemination. Knowing the facts makes the economy of the farming easier to count. Also problems and positive things can be found easier.

\section{References}

Gillham, B. Case study research methods. 2003. MPG Books Ltd. Bodmid, Cornwall.

Jahja-Hoxha, A. 2012b. A question for the thesis. [an E-mail] Receiver ArditaJahja-Hoxha. Prishtina University.arditaj@gmail.com 11.9.2012. [reference made 11.9.2012]

Nushi, M. \&Selimi, F. 2009. An assessment of the Competitiveness of the Dairy Food Chain in Kosovo [electronic publishing]. [reference made 16.11.2011] Available at: http://www.euroqualityfiles.net/AgriPolicy/Report\%202.1/Kosovo\%20Agripolicy\%20D2-1.pdf

Vehapi, I. 2009. Agriculture and Rural Development Plan 2009-13 [electronic publishing]. [reference made 17.11.2011] Available at: www.balcanicaucaso.org/eng/content/download/.../file/Strategy.pdf 